Gut, 1963, 4, 68

\title{
Histochemistry of the gastric mucosa ${ }^{1}$
}

1 In normal mucosa

\author{
J. PINTO CORREIA, M. ISABEL FILIPE, AND J. COSTA SANTOS \\ From the Departments of Pathology and Medicine, Medical School \\ of Lisbon (Hospital Santa Maria), Portugal
}

EDITORIAL SYNOPSIS This paper reports a study of the enzyme activity of the gastric mucosa obtained by oral biopsy from normal patients and from those with either gastric or duodenal ulcers or from post-gastrectomy patients. The distribution of enzyme activity between the different cells is described with special reference to the parietal cells.

There are only a few studies on the distribution of enzymes in the gastric mucosa, mostly based on experiments in animals and studying a restricted number of enzymes (Villarreal and Burgos, 1955; Martin, 1956; Chessick, 1953; Padykula, 1952). Only Niemi, Siurala, and Sundberg (1960) have investigated the distribution of diphosphopiridinenucleotide diaphorase and succinic and lactic dehydrogenase by means of biopsies of human stomach. We report a study of seven enzymes in material from biopsies of normal gastric mucosa.

\section{MATERIAL AND METHODS}

We used gastric biopsies from nine normals, all males, their ages ranging from 16 to 24 years.

The biopsies were taken with the subject fasting, using Crosby's capsule, which we have used for gastric mucosa with good results (Pinto Correia, Beirão, Bordalo, Quina, and Madeira, 1961). The localization of the capsule in the fundic region was always checked radiologically. The pieces of tissue were stretched out on flat surfaces and fixed with cold formol for $\mathbf{2 4}$ hours.

The enzymes studied were the non-specific alkaline

'This work has been supported by a grant from the Calouste Gulbenkian Foundation. phosphatases, adenosine triphosphatase (A.T.P.), 5nucleotidase, the acid phosphatases, the non-specific esterases, diphosphopiridinenucleotide diaphorase (D.P.N.), and triphosphopiridinenucleotide diaphorase (T.P.N.).

To study the alkaline and acid phosphatases we used the Gomori (1941) method, for A.T.P. and 5-nucleotidase the Wachestein method, and for esterase the naphthol method. Haematoxylin and eosin staining was used routinely, but for some sections to show the parietal cells better the Zimmermann-Marks method (Marks and Drysdale, 1957) was used. The scale for reaction intensities is from zero to ++++ .

\section{RESULTS}

DISTRIBUTION OF DIFFERENT ENZYMES IN GASTRIC MUCOSA In normal people (Table I) we verified that the principal cells show enzymatic activity with nonspecific esterases (Fig. 1), with 5-nucleotidase (Figs. 2 and 3), and with acid phosphatase (Figs. 4 and 5), being greater with the last. With esterases the reaction is diffused and spread throughout the cytoplasm, as is also the case with 5-nucleotidase and acid phosphatase, chiefly in the apical pole.

TABLE I

ENZYMATIC ACTIVITY IN THE VARIOUS ELEMENTS OF GASTRIC MUCOSA IN NORMAL INDIVIDUALS UNDER BASAL CONDITIONS

\begin{tabular}{|c|c|c|c|c|c|c|c|}
\hline Structures & $\begin{array}{l}\text { Alkaline } \\
\text { Phosphatase }\end{array}$ & A.T.P. & 5-Nucleotidase & $\begin{array}{l}\text { Acid } \\
\text { Phosphatase }\end{array}$ & Esterase & D.P.N. & T.P.N. \\
\hline $\begin{array}{l}\text { Principal cells } \\
\text { Parietal cells } \\
\text { Mucous cells } \\
\text { Blood vessels } \\
\text { Stroma } \\
\text { Muscle fibres } \\
\text { Basal membrane }\end{array}$ & +++ & $\begin{array}{l}+++ \\
++ \text { Fibres } \\
+++ \\
+ \text { Seldom }\end{array}$ & $\begin{array}{l}++(+) \\
+ \text { or }-+ \\
++(\text { rare }) \\
++ \text { Some cells } \\
+++ \\
+(+)\end{array}$ & $\begin{array}{l}+++ \\
+ \text { or }-+ \\
++ \text { (rare) } \\
++ \text { Some cells } \\
+\end{array}$ & $\begin{array}{l}+++ \\
+ \text { or }-+ \\
+ \text { Rare cells }\end{array}$ & $\begin{array}{l}+ \\
+++ \\
+ \text { or }-+ \\
+ \text { (rare) } \\
+ \text { Cells } \\
+\end{array}$ & $\begin{array}{l}-+ \\
++(+)\end{array}$ \\
\hline
\end{tabular}




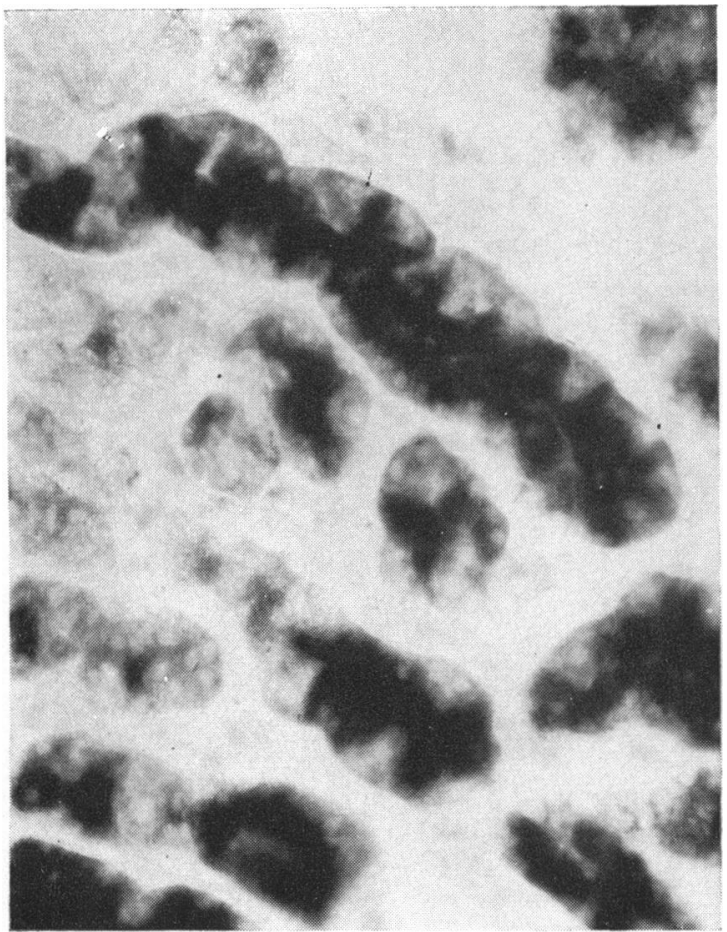

FIG. 1

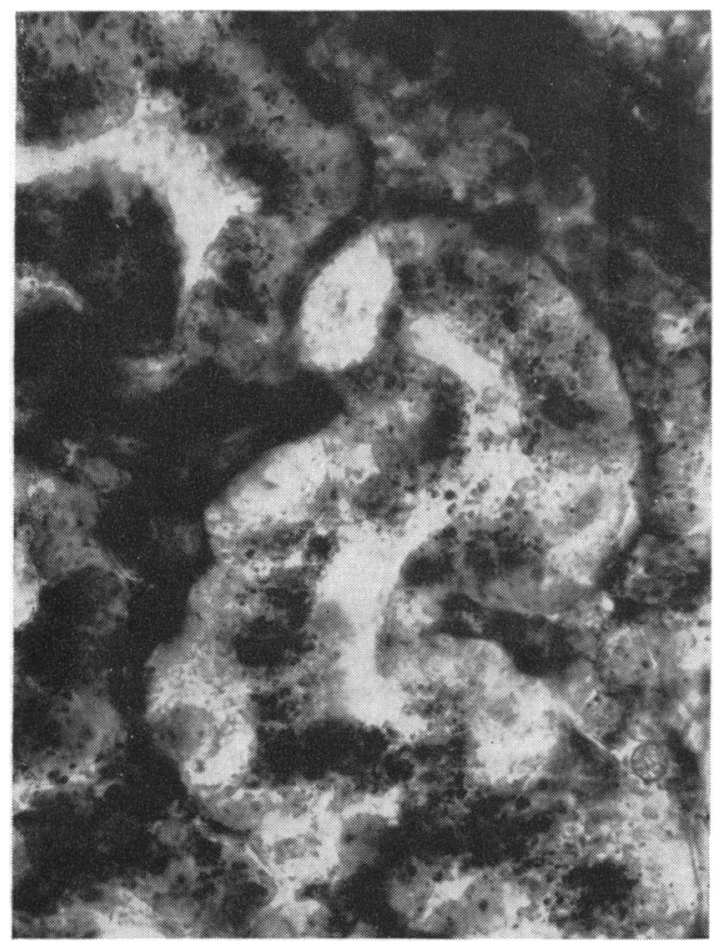

FIG. 3

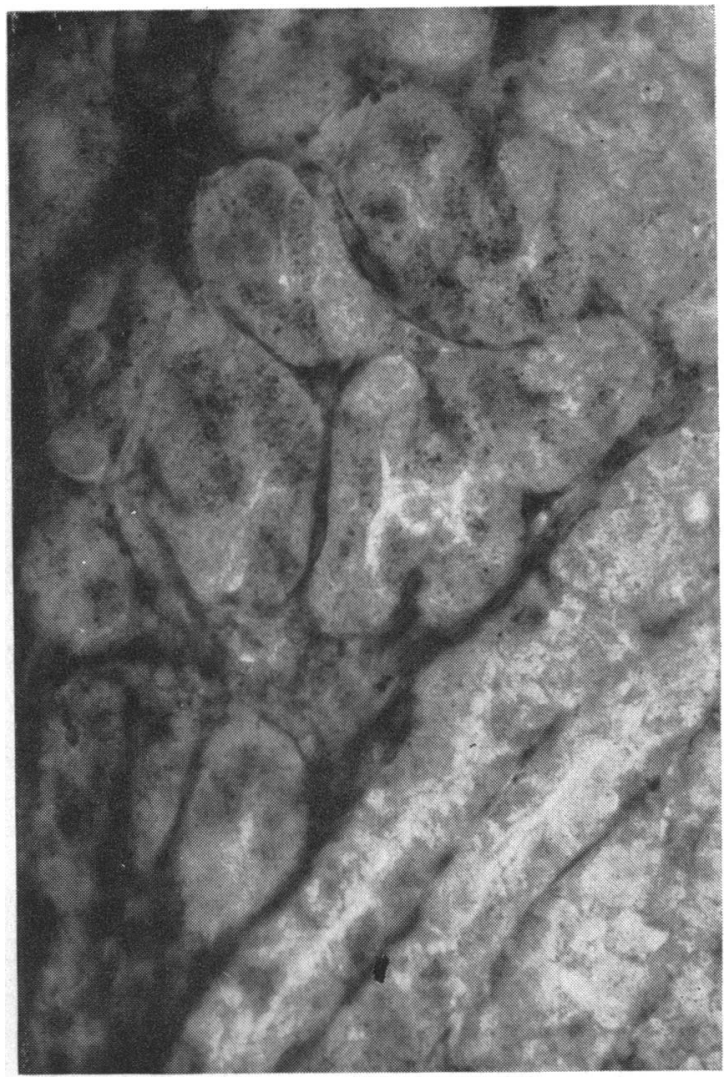

FIG. 2

FIG. 1. Non-specific esterase on the level of the principal cells in gastric mucosa.

FIG. 2. 5-Nucleotidase activity on the level of the principal cells and basal membrane of the glands in gastric mucosa. The parietal cells do not show any reaction at all.

FIG. 3. Detail of Fig. 2. 


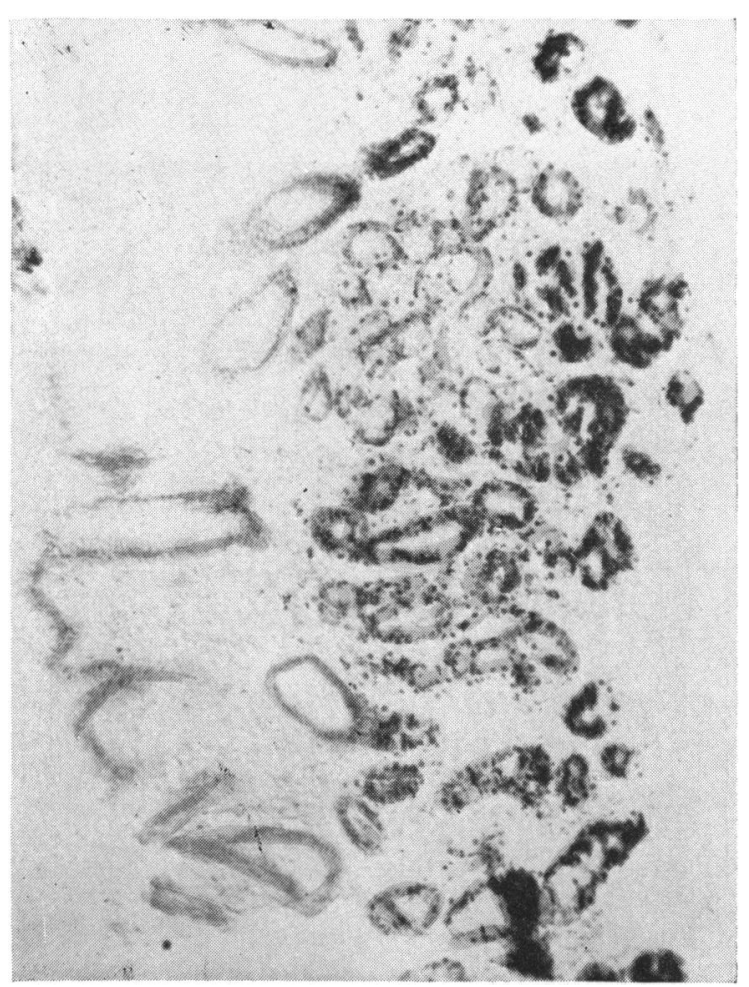

FIG. 4

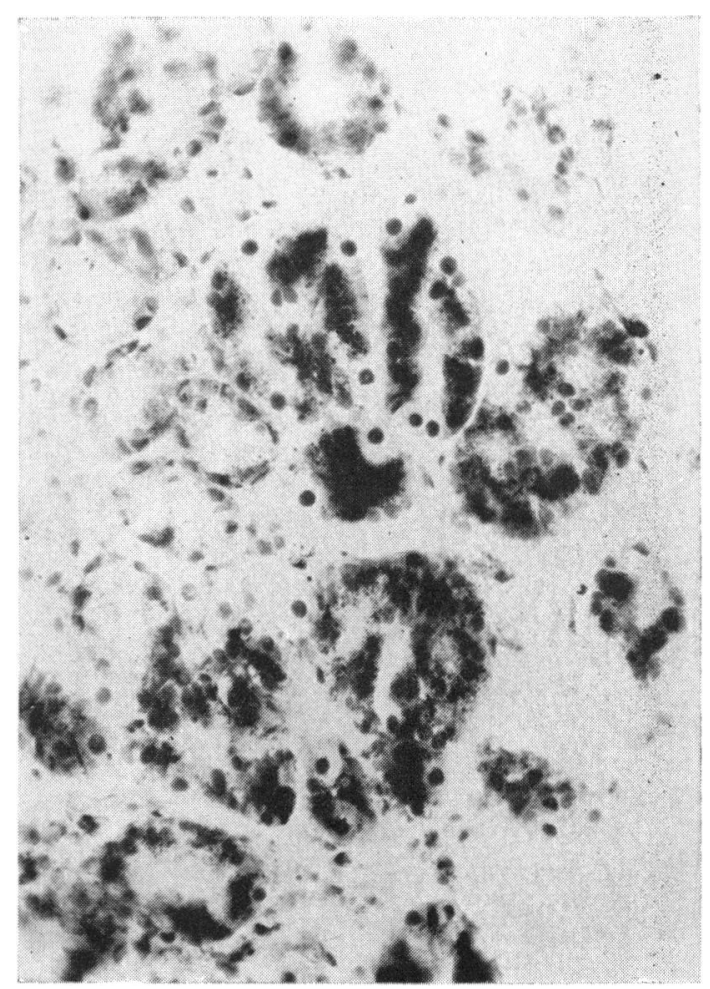

FIG. 5

FIG. 4. Enzymatic activity of the acid phosphatase on the level of the principal cells in gastric mucosa.

FIG. 5. Detail of Fig. 4.

With acid phosphatase a nuclear reaction was sometimes clearly observed. This reaction, as reported by Pearse (1960), is due to the enzyme being diffused during fixation and not to its true localization in the nucleus. With D.P.N. there is slight activity in the cytoplasm of the principal cells and a very weak reaction for T.P.N. The parietal cells, on the contrary, react strongly with D.P.N. (Fig. 6) and slightly more weakly with T.P.N. (Fig. 7). These cells do not show any activity with other enzymes.

The activity of the diaphorases is of a diffused kind in the cytoplasm of the parietal cells and starts very early. A reaction is obtained within five minutes of incubation in the medium for D.P.N. For T.P.N. it was obtained only after one hour's incubation. The number and distribution of the parietal cells in the gastric mucosa can easily be demonstrated using the reaction for D.P.N. and for T.P.N. It is similarly possible to study the distribution, number, and relative frequency of the parietal and principal cells.

In the fundic region are the mucous cells, which are part of the surface epithelium and are also found in the neck of the glands; in the body of the glands are also found parietal and principal cells, the parietal cells being more numerous in the upper half of the glands and the principal cells predominating in the lower half. In certain specimens the parietal cells were so numerous in the upper half of the glands that they were packed closely, practically without any intervening principal cells and so big that the lumen of the glands almost disappeared. This histological picture was seen most clearly in the reaction for D.P.N. but it was also visible in staining with haematoxylin and eosin and using the Zimmermann-Marks method.

The epithelial and mucous cells of the neck might give a very slight reaction or no reaction at all. Sometimes a very slight positive $(t)$ reaction concentrated around the nucleus was seen with acid phosphatase, 5-nucleotidase, the esterases, and D.P.N.

In the method for alkaline phosphatase a strong reaction was seen only in the vascular walls (Fig. 8) and mainly in those vessels located deeply in the mucosa, few of the capillaries showing any reaction in the superficial zone. Many vessels reacted to A.T.P. (Fig. 9), and throughout the section a very rich vascular network could be seen surrounding the 


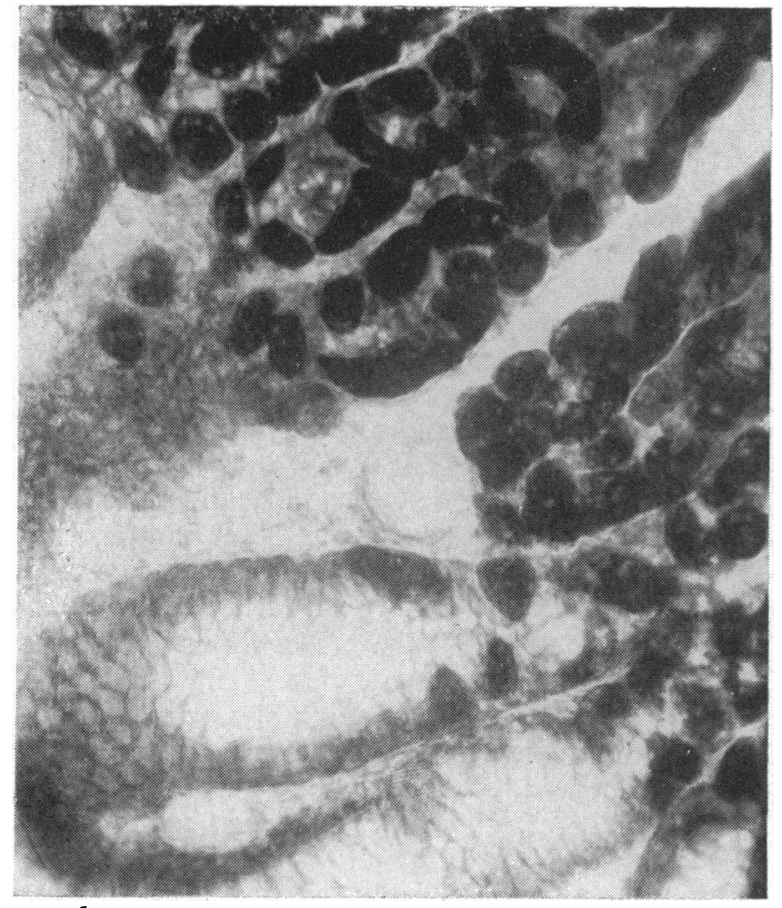

FIG. 6

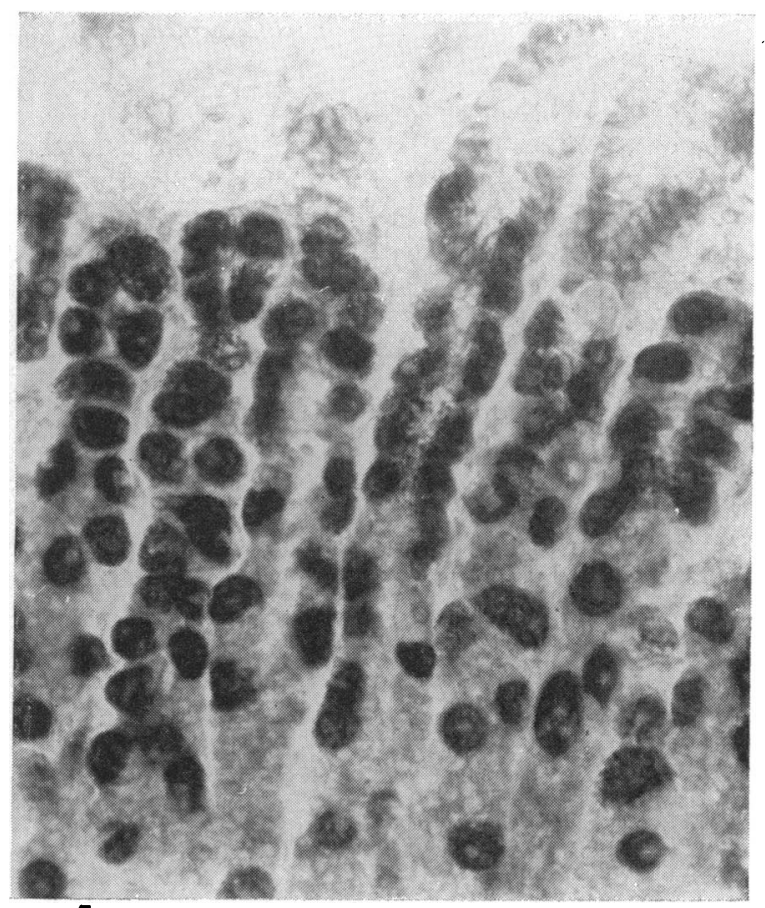

FIG. 7.

FIG. 6. Activity of D.P.N. in the parietal cells of gastric mucosa.

FIG. 7. Activity of T.P.N. in the parietal cells of gastric mucosa.

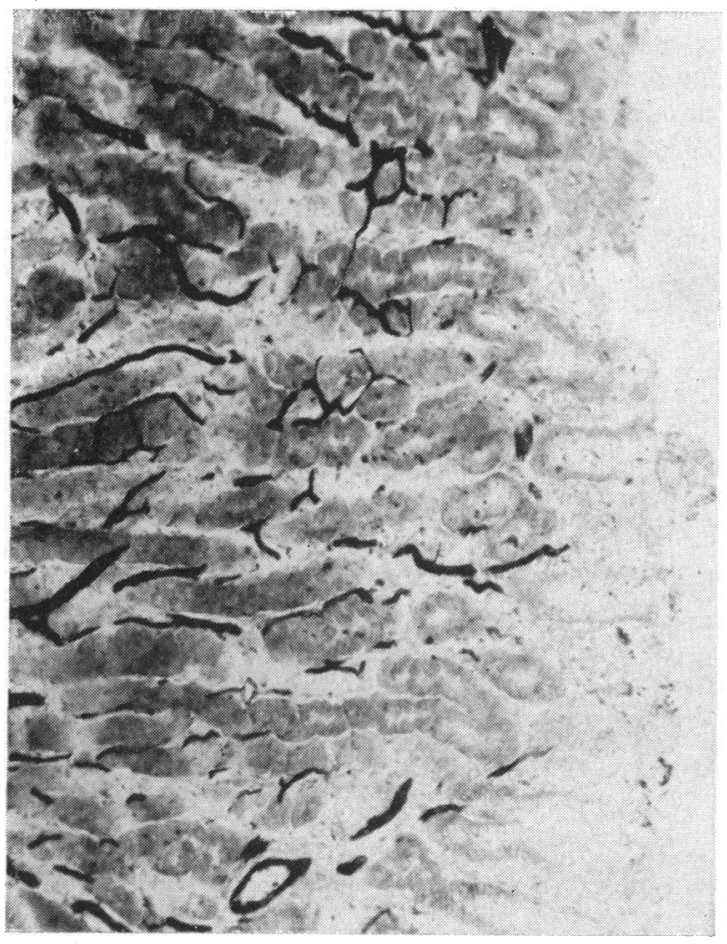

FIG. 8

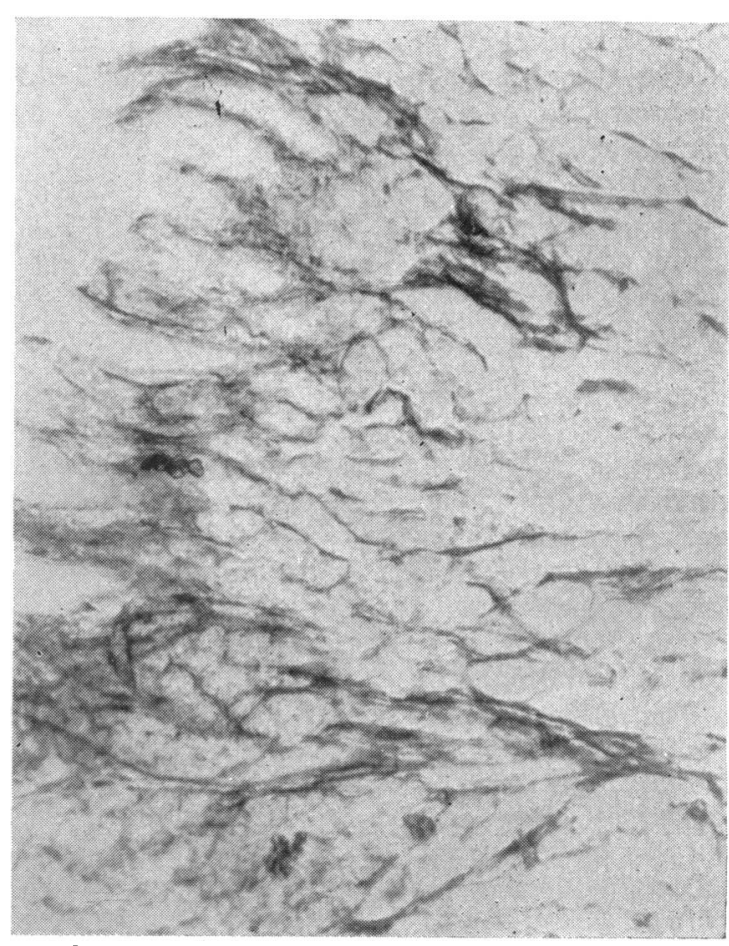

FIG. 9

FIG. 8. Non-specific alkaline phosphatase activity in gastric mucosa. FIG. 9. Activity of A.T.P. in gastric mucosa. 
glands and making with the capillaries a kind of 'plume' close to the surface of the epithelium. Enzyme activity in the capillary walls could also be seen for 5-nucleotidase and more weakly for acid phosphatase. For D.P.N., although very few capillaries presented any activity, there was a weak reaction in almost all cases.

Some cellular elements of the stroma also presented enzyme activity, although weakly, with all the enzymes studied except alkaline phosphatase and T.P.N.

Some collagenous fibres also reacted to A.T.P. Sometimes it was possible to see a moderate reaction of the basal membrane of some glands with 5nucleotidase and acid phosphatase, and less often with A.T.P.

In some sections in which the muscularis mucosae was present, the fibres reacted intensely with A.T.P. and 5-nucleotidase and weakly with T.P.N.

\section{COMMENTS}

The introduction of gastric biopsy has opened new possibilities for the study of the gastric mucosa in vivo, both from the morphological and the histochemical viewpoints, by which the functional and histological pictures can be related. Hitherto, almost all cytochemical studies, and in particular enzyme studies, have been made in animals. Our study confirms the intense activity of D.P.N. in the parietal cells and the weak reactivity of the principal and superficial cells to this enzyme. Niemi et al. (1960) found that the surface epithelial cells were negative, and the principal and some of the mucous cells of the neck weakly positive. They consider that the intense activity of the parietal cells for D.P.N. must be related to the task of these cells in producing hydrochloric acid. For this process a great deal of energy is needed and is provided by the adenosine triphosphate that is made by phosphorylation in the cycle of the tricarboxylic acid. Both D.P.N. and dehydrogenase enter this cycle, and their site and intensity can be regarded as an index of this activity. Hally (1959) has verified with the electron microscope that the parietal cells of the mouse have a great number of mitochondria, in accordance with their wide enzymatic activity; Davenport (1957) has also shown that the parietal cells of the mouse account for a large consumption of oxygen.

In our study the site of esterase in the principal cells has proved to be the same as that described by Chessick (1953) but we have not found any previous references to the sites of non-specific alkaline phosphatase, A.T.P., and 5-nucleotidase in the gastric mucosa. We have verified the site of acid phosphatase in the cytoplasm of principal cells, which had also been observed by Gomori (1956), finding no reaction in parietal cells. Rutenberg and Seligman (1955), however, and Roseman, Simon, and Sleisenger (1959), working with another method for this enzyme, refer to intense activity in the parietal cells.

\section{In pathological conditions and in changes induced by histamine}

Physiological or pharmacological processes which take place within the cell are often accompanied by enzymatic as well as by structural changes. Such correlations merit study, for the role of different enzyme systems in certain functions of the cell may thus be elucidated. The information can be particularly valuable at the present time when the functional significance of intracellular components is still little understood.

The purpose of this further study was to observe the changes in enzyme activity in the cells of human gastric mucosa, before and after stimulation of gastric secretion induced by histamines in normal subjects. The mucosa was obtained by peroral biopsies and various enzymes were demonstrated by current histochemical techniques. Although somewhat similar studies were carried out with mice and frogs (Villarreal and Burgos, 1955), work on enzyme changes in human gastric mucosa at the time of writing has apparently been confined to homogenate studies (Vitale, Jankelson, Connors, Hegsted, and Zamcheck, 1956).

\section{MATERIAL AND METHODS}

Gastric biopsies were obtained by means of the Crosby capsule as described by Crosby and Kugler (1957) Twenty patients were studied and the sex and age distribution is recorded in Table I. The group included patients who previously had had a gastrectomy for

TABLE I

\begin{tabular}{|c|c|c|c|c|}
\hline \multirow{3}{*}{ Group } & RIAL & DIE & & \multirow{3}{*}{$\begin{array}{l}\text { Age } \\
\text { Range } \\
\text { (yr.) }\end{array}$} \\
\hline & \multirow{2}{*}{$\begin{array}{l}\text { Total } \\
\text { Cases }\end{array}$} & \multicolumn{2}{|c|}{ Sex } & \\
\hline & & $M$ & $F$ & \\
\hline \multirow{4}{*}{$\begin{array}{l}\text { Duodenal ulcer } \\
\text { Duodenal and gastric ulcers } \\
\text { Gastric ulcer } \\
\text { After gastrectomy }\end{array}$} & 8 & 8 & - & $25-54$ \\
\hline & 3 & 2 & 1 & $49-63$ \\
\hline & 2 & 1 & 1 & $28-56$ \\
\hline & 7 & 6 & 1 & $29-48$ \\
\hline
\end{tabular}

